Article

\title{
Microbial Community Shifts during Biogas Production from Biowaste and/or Propionate
}

\section{Chaoran Li ${ }^{1, \dagger}$, Christoph Moertelmaier ${ }^{1, \dagger}$, Josef Winter ${ }^{1}$ and Claudia Gallert ${ }^{1,2, *}$}

1 Institute of Biology for Engineers and Biotechnology of Wastewater, Karlsruhe Institute of Technology (KIT), Am Fasanengarten, Karlsruhe D-76128, Germany;

E-Mails: chaoran.li3@kit.edu (C.L.); christoph.moertelmaier@kit.edu (C.M.); josef.winter@kit.edu (J.W.)

2 Division Microbiology-Biotechnology, Faculty of Technology, University of Applied Science, Hochschule Emden-Leer, Constantiaplatz 4, Emden D-26723, Germany

$\dagger$ These authors contributed equally to this work.

* Author to whom correspondence should be addressed; E-Mail: claudia.gallert@ hs-emden-leer.de; Tel.: +49-4921-807-1586; Fax: +49-4921-807-1593.

Academic Editor: Sabine Kleinsteuber

Received: 6 November 2014 / Accepted: 30 January 2015 / Published: 9 February 2015

\begin{abstract}
Propionate is the most delicate intermediate during anaerobic digestion as its degradation is thermodynamically unfavorable. To determine its maximum possible degradation rates during anaerobic digestion, a reactor was fed Monday to Friday with an organic loading rate (OLR) of $12 / 14 \mathrm{~kg}$ COD biowaste $\cdot \mathrm{m}^{-3} \cdot \mathrm{d}^{-1}$ plus propionate up to a final OLR of $18 \mathrm{~kg} \mathrm{COD} \cdot \mathrm{m}^{-3} \cdot \mathrm{d}^{-1}$. No feed was supplied on weekends as it was the case in full-scale. To maintain permanently high propionate oxidizing activity (POA), a basic OLR of $3 \mathrm{~kg} \mathrm{COD}$ propionate $\cdot \mathrm{m}^{-3} \cdot \mathrm{d}^{-1}$ all week $+11 \mathrm{~kg} \mathrm{COD}$ biowaste $\cdot \mathrm{m}^{-3} \cdot \mathrm{d}^{-1}$ from Monday to Friday was supplied. Finally a reactor was operated with an OLR of $12 \mathrm{~kg} \mathrm{COD}$ biowaste $\cdot \mathrm{m}^{-3} \cdot \mathrm{d}^{-1}$ from Monday to Friday and $5 \mathrm{~kg} \mathrm{COD}_{\text {propionate }} \cdot \mathrm{m}^{-3} \cdot \mathrm{d}^{-1}$ from Friday night to Monday morning to maintain a constant gas production for permanent operation of a gas engine. The propionate degradation rates (PDRs) were determined for biowaste + propionate feeding. Decreasing PDRs during starvation were analyzed. The POA was higher after propionate supply than after biowaste feeding and decreased faster during starvation of a propionate-fed rather than a biowaste-fed inoculum. Shifts of the propionate-oxidizing and methanogenic community were determined.
\end{abstract}


Keywords: anaerobic co-digestion; biowaste; propionate; propionate-oxidizing bacteria (POB); methanogenic community; community shifts

\section{Bullet Points}

Anaerobic digestion of biowaste + propionate

Periodic biowaste replacement by propionate

Propionate-oxidizing bacteria and methanogenic archaea

Constant biogas production with different substrates

Community changes during different operational conditions

\section{Introduction}

Propionate is a key intermediate of anaerobic digestion in general and of biowaste in particular [1-7]. Main sources of propionate in bioreactors are odd numbered fatty acids from lipolysis of fat and oil as well as from carbohydrate and amino acid degradation [3]. Propionate accumulates during disturbances of the anaerobic digestion process, caused by e.g., toxic substances, high dry matter content, or high OLR close to overload, when hydrolysis, acidogenesis, acetogenesis, and methanogenesis, leading to biogas formation from complex organic matter, are no longer balanced [4,7,8]. Degradation of accumulated fatty acids such as propionate, however, is thermodynamically unfavorable [9]. Only a few slow-growing and obligately syntrophic propionate-oxidizing bacteria (POB) can degrade propionate to acetate, $\mathrm{CO}_{2}$, and hydrogen in the absence of electron acceptors such as sulfate. Degradation of propionate under strictly anaerobic conditions requires a hydrogen partial pressure of $<6.5 \mathrm{~Pa}$ in a narrow thermodynamically defined window. Thus, in many anaerobic digesters high propionate concentrations can persist for a long time without failure of methane production, e.g., after start up or at high load conditions [1,4,7]. Deltaproteobacteria of the genera Syntrophobacter and Smithella, as well as Firmicutes belonging to the genera Pelotomaculum and Desulfotomaculum, are known to degrade propionate [5]. The growth rate of these POB and their community density in anaerobic digesters is, however, low. After a specific enrichment of methanogens for removal of hydrogen, doubling times of a defined methanogenic co-culture of Pelotomaculum schinkii of 1.5 days was achievable [10]. For fast propionate degradation, it is essential that acetogenic and methanogenic microorganisms have close spatial proximity to enable an optimal interspecies electron transfer [11].

As Pelotomaculum sp. [10] were the latest described genus of POB, earlier publications on propionate degradation did not cover them, although they may have been present. More recent studies revealed that Pelotomaculum sp. might represent the dominant POB group in anaerobic digestion systems. Shigematsu et al. [12], for instance, analyzed the community structure of POB in a propionate-fed chemostat at different dilution rates and found that at a dilution rate of $0.3 \mathrm{~d}^{-1}$ Pelotomaculum was the most numerous genus within the POB. Ban et al. [13] used qPCR to determine POB in a UASB reactor fed with propionate and proved that Pelotomaculum schinkii was the dominating species of POB. Ariesyady et al. [14] found high proportions of Smithella sp. and lower proportions of Syntrophobacter sp. in anaerobic sludge, but they did not determine Pelotomaculum sp. In a very recent work by Li et al. [15] 
Pelotomaculum sp. comprised $1.2 \%$ of the total prokaryotes in manure-straw co-digestion experiments. The same authors observed a positive correlation between the proportion of Pelotomaculum sp. and Methanoculleus sp., which was already reported by Shigematsu et al. [12]. Methanoculleus sp. apparently represented not only the optimal methanogenic partners for syntrophic propionate oxidation but also for syntrophic acetate oxidation, as discussed by Hori et al. [16].

Only a few studies exist in which the composition of POB in biowaste digesters was analyzed under different process conditions. McMahon et al. [1], for instance, observed that POB subgroups changed during start-up or at near-overload phases: Whereas the number of Smithella sp. declined after overload, the number of Syntrophobacter sp. remained almost unchanged. At steady state conditions the percentage of the POB (not including Pelotomaculum sp.) was 1.5-1.6\% of total prokaryotes. When in a full-scale biowaste digester in addition to Syntrophobacter sp. and Smithella sp., Pelotomaculum sp. were also analyzed, the proportion of POB within the total prokaryotes increased to $2.7-5 \%$ [7].

Fermentation of source-sorted biowaste in continuously operated anaerobic reactors at constant OLR clearly below overload should be attempted. However, due to biowaste collection only on working days, sufficient biowaste suspension may not be available on weekends or holidays. Liquid-acidified substrates from canteens might be used as substitutes for biowaste, but experience with periodic short-term partial replacement of biowaste or a complete substitution of biowaste with easy-to-handle liquid food residues that could be added over weekends without the requirement of human control is not available. In pre-acidified substrates, propionate is the most sensitive intermediate that requires a high activity of POB. A detailed knowledge of the behavior of POB and the propionate metabolism during biowaste co-digestion with propionate or alternating biowaste-propionate digestion (as a model for acidified food wastes) and the long-term behavior is missing. Thus, in this contribution a suspension of source-sorted biowaste \pm little "background-propionate" (that might originate from acidification before collection or was externally added to maintain active POB) was digested with increasing amounts of propionate as a model-substrate for pre-acidified wastewater in a fed-batch digester for 5 days per week without feeding on Saturdays and Sundays, to determine maximal propionate degradation activity. Another reactor was fed with only biowaste from Monday to Friday and only propionate over the weekend to check whether an abrupt substrate change from complex biowaste to propionic acid could maintain a stable biogas production. Propionate degradation rates and community shifts during biowaste and/or propionate digestion should be determined. The stability of propionate oxidation after biowaste and/or propionate feeding with length of starvation should also be investigated and changes of POB and methanogens during the experiments should be analyzed by fluorescence in situ hybridization.

\section{Materials and Methods}

\subsection{Source of Fresh Biowaste and Digester Residues for Inoculation of Laboratory Reactors}

One portion of source-sorted biowaste was mixed with two portions of process water for disruption of fibers in an $18-\mathrm{m}^{3}$ hydropulper. The suspension was stored in an interim $30-\mathrm{m}^{3}$ storage tank for subsequent wet anaerobic digestion in the biowaste digestion plant of Karlsruhe, Germany [2,17]. For laboratory experiments from the storage tank, $100 \mathrm{~L}$ of biowaste suspension were collected initially 
and another $100 \mathrm{~L} 55$ days later (for composition, see Table 1). The suspension was frozen in 2-L portions until use. For digestion of biowaste + propionate, respective amounts of concentrated propionic acid were mixed into the daily portion of fresh biowaste suspension, whereas for determining propionate degradation rates respective amounts of five-fold diluted propionic acid ( $200 \mathrm{~g}$ propionic acid per L, 2.7 M) were added to the reactor effluent. Although propionic acid was added it reacted to propionate in the digesters at a $\mathrm{pH}$ of around 7 and thus we use the term "propionate" in the following text. Effluent of the municipal biowaste digestion plant of Karlsruhe served for initial inoculation of the reactors.

Table 1. Composition of biowaste suspensions.

\begin{tabular}{cc}
\hline Parameters & Average Values \\
\hline Total solids, TS $(\%)$ & $6.1 \pm 0.5$ \\
Volatile solids, VS $(\%)$ & $5.2 \pm 0.4$ \\
Chemical oxygen demand, COD $\left(\mathrm{g} \cdot \mathrm{L}^{-1}\right)$ & $94-113$ \\
Total Kjeldahl Nitrogen, TKN $\left(\mathrm{g} \cdot \mathrm{L}^{-1}\right)$ & $2.2 \pm 0.2$ \\
$\mathrm{NH}_{4}{ }^{+}$-Nitrogen $\left(\mathrm{g} \cdot \mathrm{L}^{-1}\right)$ & $0.5 \pm 0.1$ \\
$\mathrm{pH}$ & 4.5 \\
Acetate $\left(\mathrm{g} \cdot \mathrm{L}^{-1}\right)$ & $3.1 \pm 0.3$ \\
Propionate $\left(\mathrm{g} \cdot \mathrm{L}^{-1}\right)$ & $2.7 \pm 0.3$ \\
$n$-Butyrate $\left(\mathrm{g} \cdot \mathrm{L}^{-1}\right)$ & $1.5 \pm 0.2$ \\
\hline
\end{tabular}

\subsection{Reactor Setup, Feeding, and Incubation Conditions}

Four cylindrical glass reactors (Figure 1) with a total volume of $10 \mathrm{~L}$ and a working volume of $8 \mathrm{~L}$, wrapped with silicon tubing for warm water circulation from a thermostat to maintain $37{ }^{\circ} \mathrm{C}$, were fed from Monday to Friday at 8 a.m. and 6 p.m. with fresh biowaste suspension, replacing $600 \mathrm{~mL}$ of digested biowaste. No feed was added on Saturday and Sunday as in the full-scale plant of Karlsruhe. The laboratory reactor 1 was run as a control for 48 days at $12 \mathrm{~kg} \mathrm{COD} \cdot \mathrm{m}^{-3} \cdot \mathrm{d}^{-1}$ OLR maintained with biowaste suspension batch 1 . Reactor 2 was also run with an OLR of $12 \mathrm{~kg} \mathrm{COD} \cdot \mathrm{m}^{-3} \cdot \mathrm{d}^{-1}$ for 55 days with the same biowaste suspension batch 1 , but after 2 weeks the OLR of $12 \mathrm{~kg} \mathrm{COD}$ biowaste $\cdot \mathrm{m}^{-3} \cdot \mathrm{d}^{-1}$ was increased to $13 \mathrm{~kg} \mathrm{COD} \cdot \mathrm{m}^{-3} \cdot \mathrm{d}^{-1}$ by propionic acid addition. After 55 days the basic OLR with biowaste suspension batch 2 was $14 \mathrm{~kg}$ CODbiowaste $\mathrm{m}^{-3} \cdot \mathrm{d}^{-1}$, which was increased stepwise by addition of respective amounts of propionic acid (addition of $0.7 \mathrm{~g}$ propionic acid per L equals an OLR increase of $1 \mathrm{~kg} \mathrm{COD} \cdot \mathrm{m}^{-3} \cdot \mathrm{d}^{-1}$ ) to a maximum of $18 \mathrm{~kg} \cdot \mathrm{m}^{-3} \cdot \mathrm{d}^{-1}$, as indicated in Table 2 and Figure $2 \mathrm{~b}$. During glass repairs (days 75-85, Figure $2 b$ ) the reactor content was stored anaerobically but was not fed. Reactor 3 was run with a basic OLR of $3 \mathrm{~kg} \mathrm{COD} \cdot \mathrm{m}^{-3} \cdot \mathrm{d}^{-1}$, maintained by propionic acid addition all week to keep the propionate-oxidizing bacteria (POB) active. Biowaste suspension was available from Monday to Friday and was added to give an additional OLR of $11 \mathrm{~kg} \mathrm{COD} \cdot \mathrm{m}^{-3} \cdot \mathrm{d}^{-1}$. Reactor 4 was fed with biowaste suspension from Monday to Friday at an OLR of $11 \mathrm{~kg} \mathrm{COD} \cdot \mathrm{m}^{-3} \cdot \mathrm{d}^{-1}$ and with propionic acid from Friday night to Monday morning at an OLR of $5 \mathrm{~kg} \mathrm{COD} \cdot \mathrm{m}^{-3} \cdot \mathrm{d}^{-1}$. With this feeding regime, the same daily gas production as with biowaste, necessary for continuous operation of a generator, was obtained. 
For analyses of propionate degradation rates, duplicate assays in serum bottles, containing $40 \mathrm{~mL}$ effluent of reactor 2 during operation at different OLRs or of reactor 4 after biowaste or propionate feeding as sources of microorganisms and $800 \pm 50 \mathrm{mg} \mathrm{L}^{-1}$ propionate, were incubated at $37{ }^{\circ} \mathrm{C}$. Samples were withdrawn with a syringe and the concentration of propionate was determined by gas chromatography. Mean degradation rates were calculated for the exponential degradation phases of propionate in the parallel assays.

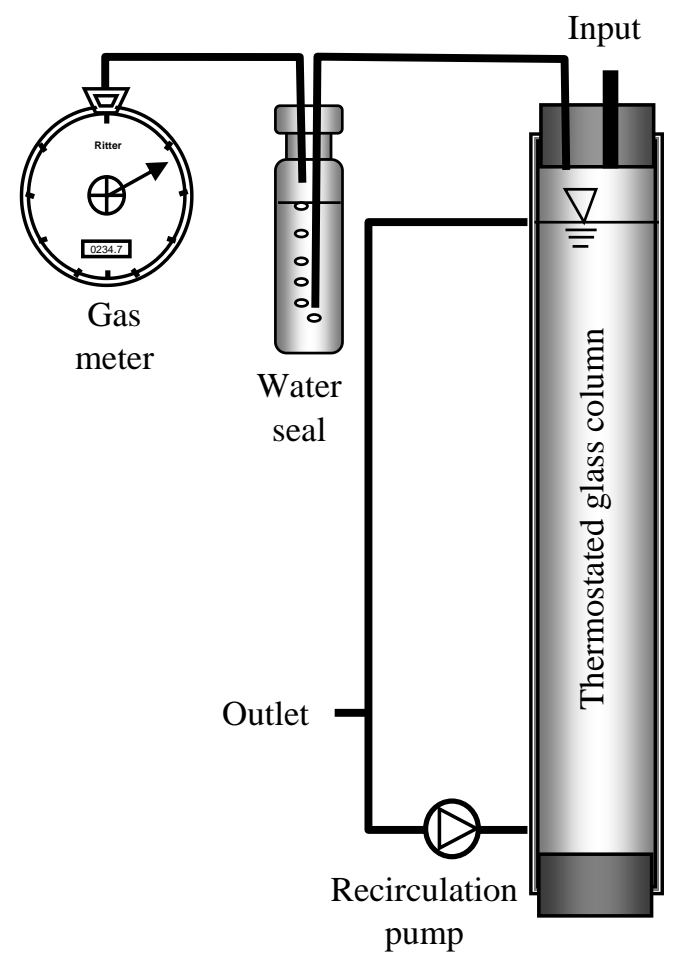

Figure 1. Scheme of reactors.

Table 2. Propionate degradation rates in reactor 2 for biowaste at an OLR of $12 / 14 \mathrm{~kg} \mathrm{COD} \cdot \mathrm{m}^{-3} \cdot \mathrm{d}^{-1}$ and after a stepwise increase of the OLR to $18 \mathrm{~kg} \mathrm{COD} \cdot \mathrm{m}^{-3} \cdot \mathrm{d}^{-1}$ by co-feeding of propionate.

\begin{tabular}{cccc}
\hline Time (days) & $\begin{array}{c}\text { OLR } \\
\left(\mathbf{k g ~ C O D} \cdot \mathbf{m}^{-\mathbf{3}} \cdot \mathbf{d}^{\mathbf{- 1}}\right)\end{array}$ & $\begin{array}{c}\text { Propionate Addition } \\
\left(\mathbf{g} \cdot \mathbf{L}^{-\mathbf{1}}\right)\end{array}$ & $\begin{array}{c}\text { Degradation Rate } \\
\left(\mathbf{m g} \cdot \mathbf{L}^{-\mathbf{1}} \cdot \mathbf{h}^{\mathbf{- 1}}\right)\end{array}$ \\
\hline 2 & 12 & - & $40.4^{\mathrm{b}}$ \\
12 & 12 & - & $41.4^{\mathrm{c}}$ \\
30 & $12+1^{\mathrm{a}}$ & 0.7 & $54.8^{\mathrm{b}}$ \\
72 & $14+2.5^{\mathrm{a}}$ & 1.5 & $70.8^{\mathrm{b}}$ \\
94 & $14+3.0^{\mathrm{a}}$ & 1.9 & $99.9^{\mathrm{b}}$ \\
117 & $14+4.0^{\mathrm{a}}$ & 2.5 & $109.2^{\mathrm{b}}$ \\
\hline
\end{tabular}

Biowaste contributed 12 (batch 1 until day 30 ) or $14 \mathrm{~kg} \mathrm{COD} \cdot \mathrm{m}^{-3} \cdot \mathrm{d}^{-1}$ (batch 2 , after day 30 ). ${ }^{\text {a Additional }}$ OLR by propionate addition, ${ }^{\mathrm{b}}$ Average propionate degradation rate $( \pm 0.3)$ determined in parallel incubations. ${ }^{\mathrm{c}}$ Average propionate degradation rate of duplicate samples $( \pm 0.3)$ of reactor 1 and reactor 2 , as well as from the full-scale biowaste reactor of the city of Karlsruhe. 

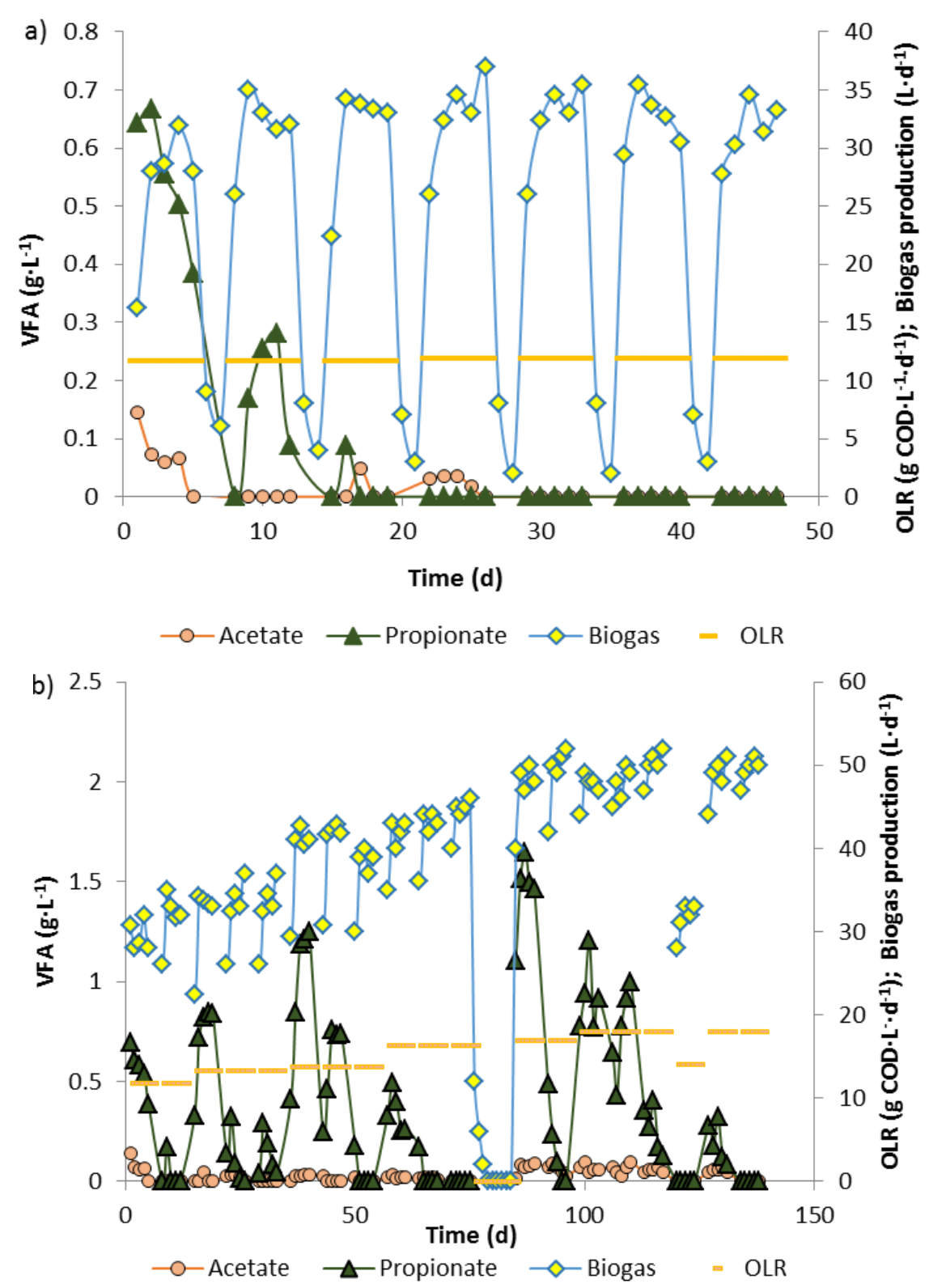

Figure 2. Biogas production and fatty acid levels in a $10 \mathrm{~L}$ biowaste reactor 1 after start at an OLR of $12 \mathrm{~kg} \mathrm{COD}$ biowaste $\cdot \mathrm{m}^{-3} \cdot \mathrm{d}^{-1}$ (a) and in reactor 2 for increasing organic loading rates up to $18 \mathrm{~kg} \mathrm{COD} \cdot \mathrm{m}^{-3} \cdot \mathrm{d}^{-1}$, maintained by $12 \mathrm{~kg}$ (day $1-55$ ) or $14 \mathrm{~kg}$ (new batch biowaste from day 55 onwards) $\mathrm{COD}$ biowaste $\cdot \mathrm{m}^{-3} \cdot \mathrm{d}^{-1}$ plus respective amounts of propionate (b). No feeding between days 75-85 due to maintenance work.

\subsection{Analyses}

Parameters of the biowaste suspension were determined according to APHA, AWWA, or WEF [18]. Ammonia was quantified with a test kit from Dr. Lange (Berlin, Germany). Acetate, propionate, i- and $n$-buyrate, as well as i- and $n$-valerate, were separated at $160{ }^{\circ} \mathrm{C}$ in a Chromosrob $\mathrm{C} 101$ Teflon column by gas chromatography with FID detection [4]. Hydrogen, methane, and carbon dioxide (detection limit $\geq 0.05 \mathrm{mmol} \cdot \mathrm{L}^{-1}$ ) were analyzed using a gas chromatograph with a thermal conductivity detector [4]. All values are the mean of at least duplicate analyses. Biogas production was analyzed with Ritter mini gas counters (BlueSens Gas Sensor GmbH, Herten, Germany). 


\subsection{Characterization of the Biowaste Community by Fluorescence in situ Hybridization (FISH)}

Samples were withdrawn from the reactors fed with biowaste or biowaste + propionate and treated according to Felchner-Zwirello et al. [10]. Parallel samples of $0.1 \mathrm{~mL}$ were mixed with $0.3 \mathrm{~mL}$ of $4 \%$ para-formaldehyde solution [19], incubated at $4{ }^{\circ} \mathrm{C}$ for $3 \mathrm{~h}$, and then centrifuged at 15,000 rpm for $5 \mathrm{~min}$ in a Microfuge (Eppendorf, Hamburg, Germany). The pellets were washed in phosphate-buffered saline solution (PBS). Samples were frozen at $-20^{\circ} \mathrm{C}$ in $1 \mathrm{~mL} 50 \%$ ethanol-PBS-solution before further analysis.

For FISH the samples were dried in ethanol, suspended in hybridization buffer, and incubated with gene probes for the domains Bacteria and Archaea, the orders Methanomicrobiales and Methanosarcinales, the genera Methanosaeta, Pelotomaculum, and Syntrophobacter, and the species Smithella propionica, as described by Li et al. [8]. After washing and counterstaining with DAPI, samples were ready for fluorescence microscopy.

\subsection{Community Density Calculation}

Fluorescence-labeled samples were viewed under a Zeiss AxioskopA50 microscope equipped with a mercury HBO 50 UV lamp and an Axiocam camera [8]. Microscopic images were processed with Axiovision 3.1 or DAIME software [20]. From each sample 10 randomly chosen microscopic view fields were photographed using the respective filters for the different fluorescent dyes. Cell numbers represent the un-weighted mean of 10 microscopic view fields of two separate sample preparations. The lowest detection limit was $1.6 \times 10^{6}$ cells $\cdot \mathrm{mL}^{-1}$.

\section{Results}

\subsection{Biowaste Digestion and Co-Digestion Strategies of Propionate}

During feeding of an anaerobic digester (reactor 1) with biowaste suspension from Monday to Friday and interruption of feeding on Saturday and Sunday, maintaining an OLR of $12 \mathrm{~kg} \mathrm{COD} \cdot \mathrm{m}^{-3} \cdot \mathrm{d}^{-1}$, propionate accumulated in the first 3 weeks during the 5 days with biowaste feeding, but was completely degraded during Saturday and Sunday, when no biowaste was supplied (Figure 1a). On this feeding schedule and for this OLR, which both represent a simulation of the full-scale operation of the biowaste digester of the city of Karlsruhe, a steady state was reached 25-27 days after start with a high enough methanogenic activity to completely degrade residual propionate and acetate during the weekend (Figure 2a). When the biowaste/microorganisms in reactor 1 were not fed with fresh biowaste suspension on Saturdays and Sundays biogas production rapidly decreased from average $34 \mathrm{~L} \cdot \mathrm{d}^{-1}$ from Tuesday to Friday to less than $5 \mathrm{~L} \cdot \mathrm{d}^{-1}$ until Monday morning. After resuming biowaste feeding, on Mondays biogas generation (Figure 2a, days 8, 15, 22, 29, 36, 43) was much lower than on Tuesday till Friday, indicating metabolic limitations. Only about 35 days after start was the metabolic activity of the community stable and high enough so that after starvation and resuming feeding on Monday only slightly less biogas $\left(28-30 \mathrm{~L} \cdot \mathrm{d}^{-1}\right)$ was produced than from Tuesday to Friday $\left(31-35 \mathrm{~L} \cdot \mathrm{d}^{-1}\right)$. 

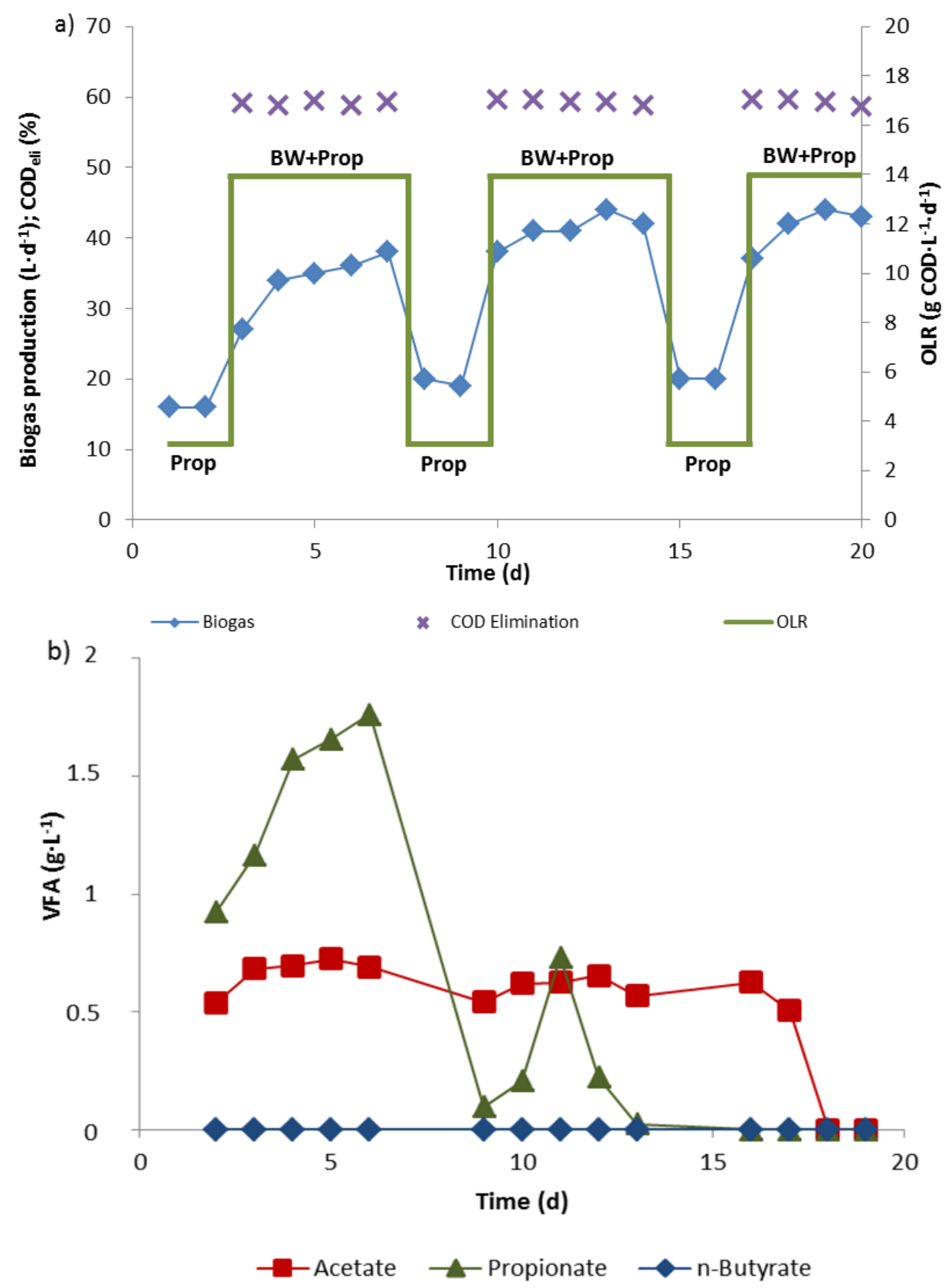

Figure 3. Biogas production (a) and fatty acid levels (b) in a $10 \mathrm{~L}$ biowaste digester (reactor 3) fed constantly with propionate $\left(2.68 \mathrm{mM}, 80 \mathrm{~mL} \cdot \mathrm{d}^{-1}\right.$ ) at an OLR of $3 \mathrm{~kg} \mathrm{COD} \cdot \mathrm{m}^{-3} \cdot \mathrm{d}^{-1}$ and additionally with biowaste from Monday to Friday $\left(1 \mathrm{~L} \cdot \mathrm{d}^{-1}\right)$ to reach an OLR of $14 \mathrm{~kg}$ COD $\cdot \mathrm{m}^{-3} \cdot \mathrm{d}^{-1}$.

Another reactor (reactor 2) was operated with a basic OLR of 12 (day $1-55$ ) or $14 \mathrm{~kg} \mathrm{COD}$ biowaste $\cdot \mathrm{m}^{-3} \cdot \mathrm{d}^{-1}$ (day 55 onwards) and the high basic load was stepwise increased to $18 \mathrm{~kg} \mathrm{COD} \cdot \mathrm{m}^{-3} \cdot \mathrm{d}^{-1}$ by co-feeding increasing amounts of propionate (Figure 2b). After every increase of the OLR, during the week high amounts of propionate (higher than the added propionate) accumulated, which were degraded during the starvation periods on weekends. For each stepwise increased OLR, propionate accumulation during the second week of feeding was significantly lower than during the first week and no propionate or only very little propionate accumulated in the third week. With increasing OLR, gas production increased with lower values on Monday than from Tuesday to Friday (Figure 2b, days 0-75), 
indicating some activity stagnation during the weekends without feeding. During 10 days' interruption of the feeding for glass repairs (Figure 2b, day 75-85), POB lost much of their metabolic activity. After resuming biowaste + propionate feeding at almost the same OLR as before maintenance, when no propionate was detected in the digester effluent, the highest propionate peak of all was measured (Figure 2b, day 89). Complete regeneration of the propionate degradation activity by POB took more than 40 days. Finally, at the very high OLR of $18 \mathrm{~kg} \mathrm{COD} \cdot \mathrm{m}^{-3} \cdot \mathrm{d}^{-1}$, maintained with biowaste + propionate feeding for 5 days per week with no feeding on Saturday and Sunday, steady state conditions without residual fatty acids in the effluent were obtained (Figure 2b, days 130-140 and further).

A third reactor (reactor 3 ) was operated with $3 \mathrm{~kg} \mathrm{COD}$ propionate $\cdot \mathrm{m}^{-3} \cdot \mathrm{d}^{-1}$ as a "background" OLR all week to maintain a steadily high propionate oxidation activity. From Monday to Friday biowaste suspension was additionally supplied to raise the OLR to $14 \mathrm{~kg} \mathrm{COD} \cdot \mathrm{m}^{-3} \cdot \mathrm{d}^{-1}$ (Figure 3). The minimal biogas production with propionate alone during weekends was $16-18 \mathrm{~L} \cdot \mathrm{d}^{-1}$. It increased to more than $40 \mathrm{~L} \cdot \mathrm{d}^{-1}$ when the OLR was increased Monday to Friday by feeding fresh biowaste suspension (Figure 3a). Two weeks after the start, no propionate accumulated in the $10 \mathrm{~L}$ reactor during the week anymore, when the OLR was raised from $3 \mathrm{~kg} \mathrm{COD}$ propionate $\cdot \mathrm{m}^{-3} \cdot \mathrm{d}^{-1}$ to $14 \mathrm{~kg} \mathrm{COD} \cdot \mathrm{m}^{-3} \cdot \mathrm{d}^{-1}$ by biowaste addition. Acetate in the effluent disappeared completely after 3 weeks (Figure 3b).

A fourth reactor (reactor 4) was run with biowaste feeding at an OLR of $12 \mathrm{~kg} \mathrm{COD} \cdot \mathrm{m}^{-3} \cdot \mathrm{d}^{-1}$ from Monday until Friday and with propionate feeding at an OLR of $5 \mathrm{~kg} \mathrm{COD} \cdot \mathrm{m}^{-3} \cdot \mathrm{d}^{-1}$ from Friday night to Monday morning to maintain a constant gas production 7 days a week (Figure 4a). No propionate or acetate was detected in the digester effluent at any time. Thus the fermentation was stable, representing steady state conditions.

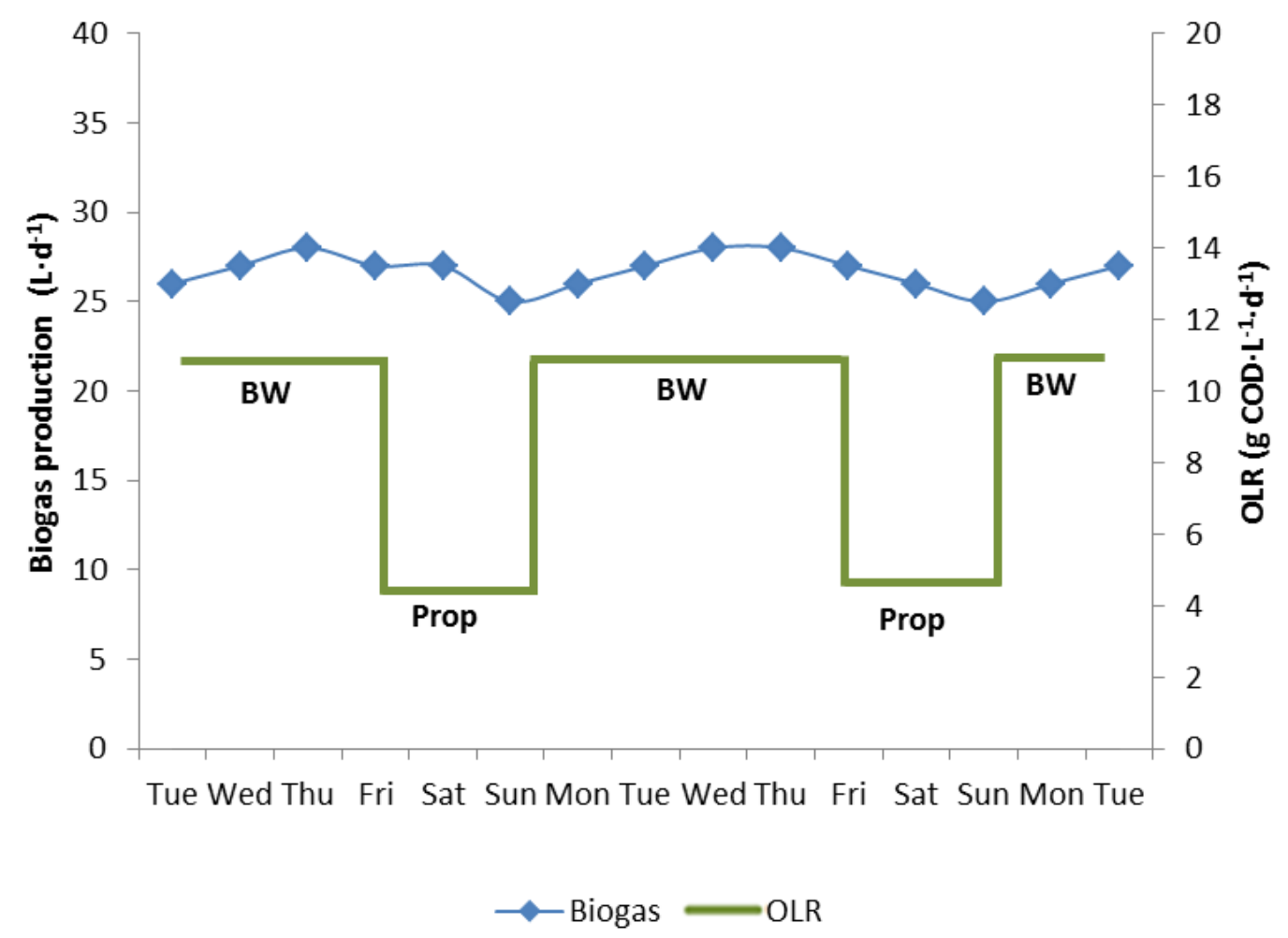

Figure 4. Periodic feeding of biowaste $\left(\mathrm{BW}, 1 \mathrm{~L} \cdot \mathrm{d}^{-1}\right.$ ) or propionate (Prop, $2.68 \mathrm{M}, 120 \mathrm{~mL} \cdot \mathrm{d}^{-1}$ ) to maintain an almost constant gas production in the $10 \mathrm{~L}$ biowaste reactor 4 over weekends, when no biowaste was available. No fatty acids were detected at any time. 


\subsection{Propionate Degradation Rates}

Propionate degradation rates (PDRs) at an OLR of $12 \mathrm{~kg} \mathrm{COD}$ biowaste $\mathrm{m}^{-3} \cdot \mathrm{d}^{-1}$ in reactor 1 or 2 (Table 2) did not change with time and were between 40.4 and $41.4 \mathrm{mg} \cdot \mathrm{L}^{-1} \cdot \mathrm{d}^{-1}$. The PDRs in reactor 2 with a high basic OLR of $12 / 14 \mathrm{~kg}$ COD biowaste $\cdot \mathrm{m}^{-3} \cdot \mathrm{d}^{-1}$ plus increasing amounts of propionate at the final OLR of $18 \mathrm{~kg} \mathrm{COD} \cdot \mathrm{m}^{-3} \cdot \mathrm{d}^{-1}$ increased to $109.2 \mathrm{mg} \cdot \mathrm{L}^{-1} \cdot \mathrm{d}^{-1}$ (Table 2) and to $100 \mathrm{mg} \cdot \mathrm{L}^{-1} \cdot \mathrm{d}^{-1}$ in only propionate-fed reactor 4 . PDRs increased with the addition of propionate (Table 2).

a) Propionate degradation rates

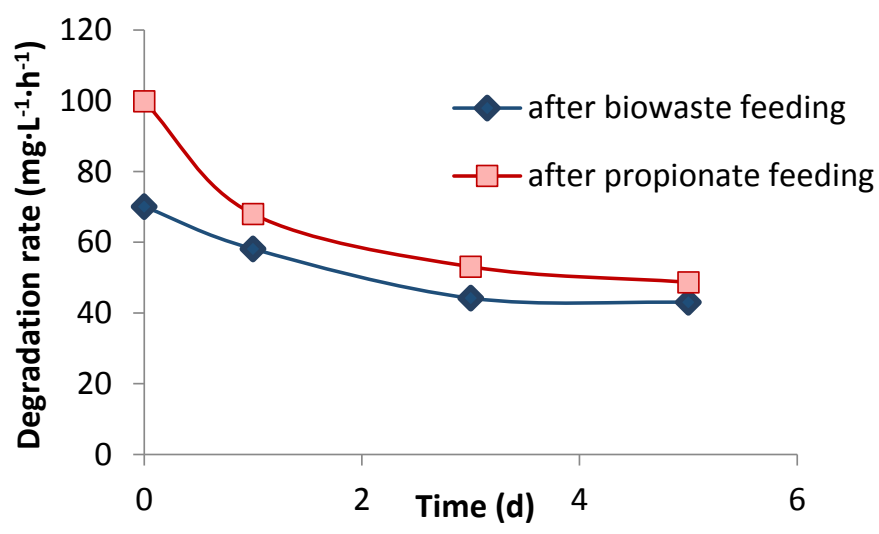

b) After biowaste feeding
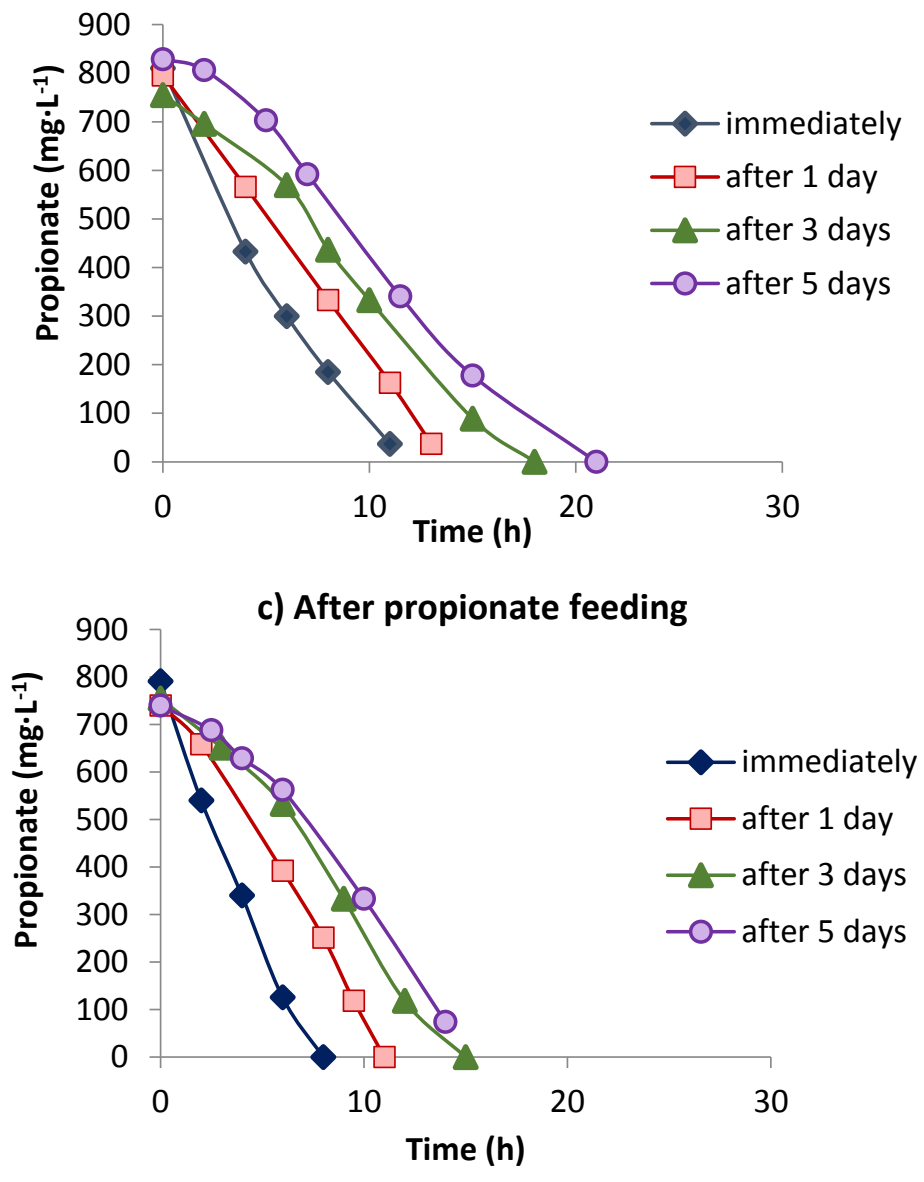

Figure 5. Propionate degradation rates (a) and degradation activity immediately following starvation in effluent of reactor 4 or after 1-5 days, after biowaste (b) or propionate feeding (c). 
In reactor 4 with successive feeding of $12 \mathrm{~kg} \mathrm{COD}$ biowaste $\cdot \mathrm{m}^{-3} \cdot \mathrm{d}^{-1}$ for 5 days and $5 \mathrm{~kg} \mathrm{COD}$ propionate $\cdot \mathrm{m}^{-3} \cdot \mathrm{d}^{-1}$ for 2 days over the weekend, resulting in an identical daily gas productivity, sludge withdrawn after biowaste feeding had a PDR of $70 \mathrm{mg} \cdot \mathrm{L}^{-1} \cdot \mathrm{h}^{-1}$ (Figure 5a), which was almost double (70 compared to $40 \mathrm{mg} \cdot \mathrm{L}^{-1} \cdot \mathrm{d}^{-1}$ ) that in the only biowaste-fed reactor 2 (Table 2) at the same loading (Figure 2a; Table 2). Sludge that was withdrawn after 2 days of only propionate feeding had a much higher PDR of $100 \mathrm{mg} \cdot \mathrm{L}^{-1} \cdot \mathrm{h}^{-1}$, compared to the PDR of $109.3 \mathrm{mg} \cdot \mathrm{L}^{-1} \cdot \mathrm{h}^{-1}$ in reactor 2 with $14 \mathrm{~kg} \mathrm{COD}$ biowaste $\cdot \mathrm{m}^{-3} \cdot \mathrm{d}^{-1}$ $+4 \mathrm{~kg} \mathrm{COD}$ propionate $\cdot \mathrm{m}^{-3} \cdot \mathrm{d}^{-1}$. However, during the first day of starvation the PDR decreased much faster in the sludge-fed propionate than in the sludge-fed biowaste (Figure 5a). About 30-50\% of the propionate oxidizing activity (POA) was lost during 5 days of starvation, and degradation of propionate in the assays had started already after 3 days' starvation, after a lag phase of 4-7 h (Figure 5b,c). Propionate degradation was completed much earlier in propionate-fed sludge than in biowaste-fed sludge (Figure 5b,c). While during the first day of starvation POA in the propionate-fed sludge decreased much faster than in the biowaste-fed sludge ( $30 \%$ versus $13 \%)$, later on the POA in both assays decreased at similar rates (Figure 5a).

\subsection{Community Changes during Biowaste and Propionate Degradation}

Community changes were investigated in reactor 2, which was fed with biowaste suspension at an OLR of $12 \mathrm{~kg} \mathrm{COD} \cdot \mathrm{m}^{-3} \cdot \mathrm{d}^{-1}$ until day 55 (batch 1) and $14 \mathrm{~kg} \mathrm{COD} \cdot \mathrm{m}^{-3} \cdot \mathrm{d}^{-1}$ from day 55 onwards (batch 2) as well as with increasing amounts of propionate, up to a final OLR of $18 \mathrm{~kg} \mathrm{COD} \cdot \mathrm{m}^{-3} \cdot \mathrm{d}^{-1}$. After only biowaste feeding at an OLR of $12 \mathrm{~kg} \mathrm{COD} \cdot \mathrm{m}^{-3} \cdot \mathrm{d}^{-1}$, the bacterial community consisted of $(2 \pm 1.1) \times 10^{9}$ Bacteria and $(0.6 \pm 0.35) \times 10^{9}$ Archaea per $\mathrm{mL}$. When the OLR of $12 \mathrm{~kg}$ CODbiowaste $\cdot \mathrm{m}^{-3} \cdot \mathrm{d}^{-1}$ was increased by $1 \mathrm{~kg} \mathrm{COD}$ propionate $\mathrm{m}^{-3} \cdot \mathrm{d}^{-1}$ the Bacteria increased within less than 10 days to their maximum cell density. Highest cell densities of Archaea and highest biogas production were, however, reached about 60 days later (Figures $2 \mathrm{~b}, 6 \mathrm{a}$ ), when up to $2.5 \mathrm{~kg} \mathrm{COD}$ propionate $\mathrm{m}^{-3} \cdot \mathrm{d}^{-1}$ were supplied in addition to $14 \mathrm{~kg}$ COD biowaste $\cdot \mathrm{m}^{-3} \cdot \mathrm{d}^{-1}$, presumably due to much slower growth rates of hydrogenotrophic and/or aceticlastic methanogens than of heterotrophic bacteria. More propionate (up to $4 \mathrm{~kg} \mathrm{COD} \cdot \mathrm{m}^{-3} \cdot \mathrm{d}^{-1}$ ) in the presence of $14 \mathrm{~kg} \mathrm{CODbiowaste} \cdot \mathrm{m}^{-3} \cdot \mathrm{d}^{-1}$ did not lead to further growth and higher community densities of Bacteria and Archaea (Figure 6a, day 85 onwards).

During revision of reactor 2 ( 1 week interruption without feeding from day 75-85) Bacteria survived almost completely, whereas the Archaea apparently suffered from starvation and cell numbers decreased more than 50\%, e.g., by cell lysis (Figure 6a). Recovery of the Archaea after resuming biowaste + propionate feeding required about 10 days. Addition of propionate to the biowaste reactor resulted in a more than 5-fold increase of the numbers of Archaea from 0.6 to $3.4 \times 10^{9}$ per mL (Figure 6a).

During biowaste digestion, less than $10 \%\left(1.5 \times 10^{8}\right.$ per $\left.\mathrm{mL}\right)$ of the Bacteria were propionate-oxidizing bacteria (POB). When $1-1.5 \mathrm{~kg} \mathrm{COD}$ propionate $\cdot \mathrm{m}^{-3} \cdot \mathrm{d}^{-1}$ were fed in addition to $12 \mathrm{~kg} \mathrm{COD}$ biowaste $\cdot \mathrm{m}^{-3} \cdot \mathrm{d}^{-1}$ the community of $\mathrm{POB}$ increased more than 3 -fold within less than 30 days to at least $5 \times 10^{8}$ per mL (Figure 6b). Most of the POB belonged to the genus Pelotomaculum. Only about $10 \%$ of the POB were species of Syntrophobacter and only about $1 \%$ of the POB were species of Smithella (Figure 6c). During feeding of 1 or $1.5 \mathrm{~kg} \mathrm{COD}$ propionate $\cdot \mathrm{m}^{-3} \cdot \mathrm{d}^{-1}$ and $12 \mathrm{~kg} \mathrm{COD}$ biowaste $\cdot \mathrm{m}^{-3} \cdot \mathrm{d}^{-1}$, all POB genera increased to their maximum cell density (Figure 6c). If more propionate was co-fed the community density of POB did not increase further, but Smithella sp. seemed to be less tolerant to high propionate 
concentrations or were less competitive against upcoming POB and their numbers decreased, similar to during starvation (Figure 6c, day 80 ). Highest cell numbers for Pelotomaculum were $(7.1 \pm 4.1) \times 10^{8}$ per $\mathrm{mL}$ and for Syntrophobacter $(2.2 \pm 1.6) \times 10^{8}$ per $\mathrm{mL}$ (Figure $6 \mathrm{c}$ ) and members of both genera survived starvation for one week without a decrease of cell numbers.
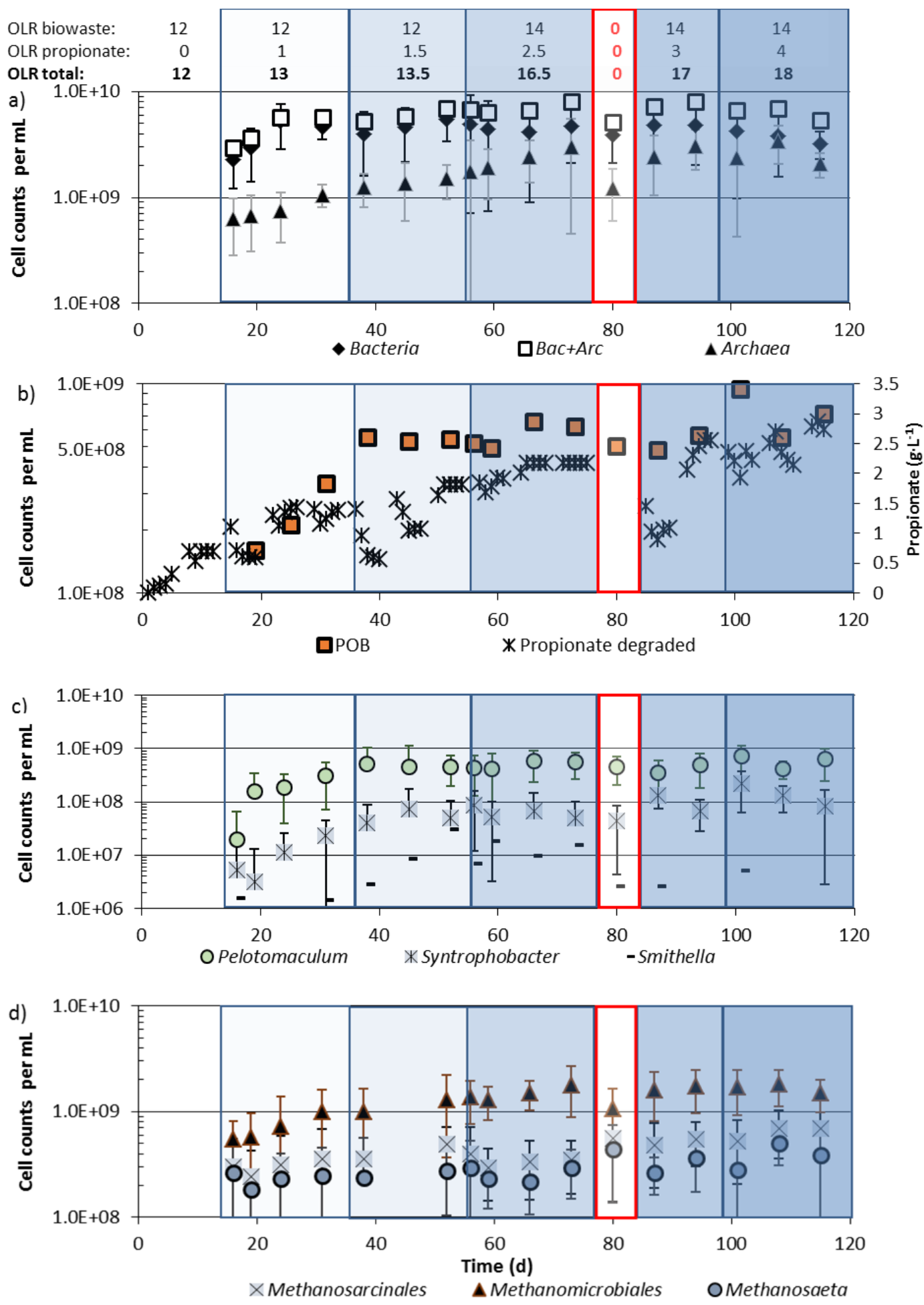

Figure 6. Total Bacteria and Archaea (a), propionate-oxidizing bacteria (POB; b, c), and methanogenic archaea (d) in reactor 2, during feeding of biowaste at an OLR of 12 (day 1-55) or 14 (day 55 onwards) $\mathrm{kg}$ CODbiowaste $\cdot \mathrm{m}^{-3} \cdot \mathrm{d}^{-1}$ and propionate up to $4 \mathrm{~kg}$ $\mathrm{COD}$ propionate $\cdot \mathrm{m}^{-3} \cdot \mathrm{d}^{-1}$. For sample preparation see Section 2.4 . 
Within the community of methanogenic archaea, Methanosarcinales (acetate-utilizing Methanosaeta and Methanosacina sp.) as well as Methanomicrobiales $\left(\mathrm{H}_{2} / \mathrm{CO}_{2}\right.$-utilizing methanogens) increased in the first 40 days after propionate co-feeding, when Methanosarcinales reached their maximum cell density. The cell density of Methanomicrobiales still increased up to day 75 (Figure 6d). If cell densities of Methanomicrobiales and Methanosarcinales correlated with metabolic activity, and methane production rates of members of both orders were the same, then most biogas released at high OLRs must come from Methanomicrobiales since their cell numbers still increased, while the number of Methansarcinales stagnated at an OLR of $13.1 \mathrm{~kg} \mathrm{COD} \cdot \mathrm{m}^{3} \cdot \mathrm{d}^{-1}$ (Figure $6 \mathrm{~d}$ ).

Within the archaeal domain the majority of species were members of the order Methanomicrobiales. In the reactor fed with biowaste and propionate, numbers of Methanomicrobiales increased from 0.5 to $2 \times 10^{9}$ per $\mathrm{mL}$. The numbers of Methanomicrobiales increased more after addition of propionate than those of the Methanosarcinales, which were present at much lower cell densities (Figure 6d). In the reactor fed biowaste + propionate (Figure 6d) and in the reactor fed with biowaste alone, the genus Methanosaeta (55-84\%) represented the majority within the Methanosarcinales [6].

\section{Discussion}

\subsection{Physiological Aspects of Biowaste and/or Propionate Degradation}

Under steady state conditions during anaerobic digestion of biowaste and/or propionate, production rates must match with conversion rates to biogas. During stepwise increase of the OLR in the biowaste digester by biowaste or propionate addition acetogenic bacteria and methanogenic archaea or methanogenic archaea, respectively, were limiting factors for quantitative degradation. If the OLR in the biowaste reactor was stepwise increased, after each increase acetate and/or propionate were found in the reactor effluent for a few days and then disappeared (Figure 2) or stabilized at a much lower concentration [2], apparently due to bacterial growth or activity gain. At a high OLR of $16-18 \mathrm{~g} \mathrm{COD} \cdot \mathrm{L}^{-1} \cdot \mathrm{d}^{-1}$, in the first week propionate concentrations reached $1-1.6 \mathrm{~g} \cdot \mathrm{L}^{-1}$. With time all propionate disappeared, at the latest during weekends without feeding, as similarly observed by Gallert et al. [2]. In the presence of inhibitors, or at high loading close to overload conditions, the capacity of methanogenesis may be exceeded and fatty acids such as propionate or acetate and n-butyrate begin to accumulate. Fatty acids in the effluent indicate incomplete methanogenesis, but some residual propionate in the effluent must not necessarily indicate already a breakdown of biogas production. Pullammappallil et al. [21] observed that during phenol inhibition in a glucose-fed anaerobic digester $2.75 \mathrm{~g} \cdot \mathrm{L}^{-1}$ propionate and about $0.1 \mathrm{~g} \cdot \mathrm{L}^{-1}$ acetate as well as n-butyrate accumulated, but methanogenesis did not collapse. Amani et al. [22] showed that propionate concentrations in an anaerobic digester significantly influenced propionate degradation. When the propionate concentration was $3 \mathrm{~g} \cdot \mathrm{L}^{-1}, 17 \%$ less propionate was removed than at a lower concentration of only $1.5 \mathrm{~g} \cdot \mathrm{L}^{-1}$. After addition of propionic acid and during stepwise increase of the OLR with biowaste, propionate concentrations in the effluent of our biowaste reactors sharply increased during the first days, but the propionate was completely degraded during weekends without feeding. POB and propionate degradation activity increased with time and almost no propionate accumulated in the third week of propionate feeding at the same OLR. The maximum propionate accumulation was $1.6 \mathrm{~g} \cdot \mathrm{L}^{-1}$ in reactor effluent, when $1.9 \mathrm{~g} \cdot \mathrm{L}^{-1}$ propionate was added with the feed. The effluent propionate concentration 
represented external addition plus internal production by fermenting bacteria minus degradation by syntrophic interaction of $\mathrm{POB}$ and methanogens. Biogas production increased with time and the $\mathrm{pH}$ in the digester remained stable throughout the stepwise increase of the OLR up to $18 \mathrm{~kg} \mathrm{COD} \cdot \mathrm{m}^{-3} \cdot \mathrm{d}^{-1}$ with biowaste and propionate co-feeding. There was a strong Pearson correlation of added propionate and biogas production of 0.86 until day 90 for an OLR of $14 \mathrm{~kg}$ COD biowaste $+2.5 \mathrm{~kg} \mathrm{COD}$ propionate $\cdot \mathrm{m}^{-3} \cdot \mathrm{d}^{-1}$. When more propionate was added (Figure 2b, day 85-140), biogas production no longer increased, indicating not only a reduced biowaste methanation but presumably also reduced acidification, since no fatty acids were accumulating and the previously accumulated propionate was apparently degraded over time. Thus the addition of $2.5 \mathrm{~kg} \mathrm{COD}$ propionate $\cdot \mathrm{m}^{-3} \cdot \mathrm{d}^{-1}$ together with $14 \mathrm{~kg} \mathrm{COD}$ biowaste $\cdot \mathrm{m}^{-3} \cdot \mathrm{d}^{-1}$ was the maximum amount for co-digestion at maximal degradation efficiency and maximal biogas production.

In Karlsruhe, Germany, source-sorted municipal biowaste is collected Monday to Friday and a biowaste suspension for anaerobic digestion prepared on the same day. Since the storage capacity for the biowaste suspension is limited, the suspension is digested on the same day. Storage of freshly collected biowaste from Friday until Monday morning is avoided to prevent spoilage by biocide-forming Phycomycetes which might inhibit methanogenesis. No storage tank for digested suspension is available, requiring solid separation by centrifugation immediately after removal of digested biowaste suspension from the reactor. Thus, a sufficient biogas amount for operation of a gas engine and an electricity generator is available during working days and only very little biogas is produced during weekends without fresh feed. To overcome this restriction, removal of biowaste suspension to the minimum filling level of the reactor on Friday night and automatic addition of highly concentrated pre-acidified liquid wastes during the weekend up to the maximum filling level on Monday morning would allow a constant gas production, as shown here with propionic acid as a "model liquid waste." Nayono et al. [17,23] reported already that fine-particles containing suspensions of highly concentrated food waste or press water from biowaste would be suitable substrates for automatic pump feeding of biowaste digesters during weekends. Such substrates are much more homogeneous than biowaste and would allow plant operation in the absence of inspecting staff. Acidified liquid substrates with high concentrations of fatty acids such as acetate, propionate, or n-butyrate might be used for automatic feeding of a biowaste reactor during phases when no biowaste is available, since these volatile fatty acids could be rapidly degraded without a significant lag-phase immediately after biowaste feeding. A rapid degradation of volatile fatty acids containing liquid wastes is possible even when no fatty acids remain in the reactor effluent during the week, as shown in this study. Since fatty acids such as propionate in acidified substrates are $100 \%$ degradable in syntrophic associations of acetogenic bacteria and methanogenic archaea, for a similar biogas production a much lower OLR is necessary during feeding of highly concentrated acidified substrates than during feeding of complex biowaste suspensions, which are only degradable to an extent of $50-70 \%[17,23]$.

\subsection{Community Shifts during Propionate Degradation}

When the OLR of reactor 2 was increased from $12 \mathrm{~kg} \mathrm{COD} \cdot \mathrm{m}^{-3} \cdot \mathrm{d}^{-1}$ to $13 \mathrm{~kg} \mathrm{COD} \cdot \mathrm{m}^{-3} \cdot \mathrm{d}^{-1}$ by propionate addition, the community density of Bacteria reached its maximum within a few days and then remained stable, even when the OLR was further increased with propionate addition, whereas the Archaea grew much more slowly and cell numbers increased only over a wide range of increasing 
OLRs (Figure 6a). This led to changing proportions of Bacteria and Archaea in the digester. At a propionate contribution of $1 \mathrm{~kg} \mathrm{COD} \cdot \mathrm{m}^{-3} \cdot \mathrm{d}^{-1}$ to the total OLR of $13 \mathrm{~kg} \mathrm{COD} \cdot \mathrm{m}^{-3} \cdot \mathrm{d}^{-1}$ in the biowaste reactor, the percentage of Archaea within the total community was $18 \%$ (Figure 6a, day 32). When propionate contributed $4 \mathrm{~kg} \mathrm{COD} \cdot \mathrm{m}^{-3} \cdot \mathrm{d}^{-1}$ to the total OLR of $18 \mathrm{~kg} \mathrm{COD} \cdot \mathrm{m}^{-3} \cdot \mathrm{d}^{-1}$, the proportion of Archaea increased to $40 \%$ of total prokaryotes (Figure 6a, day 100-120). This was double the highest report by McMahon et al. [1], who fed their digester with a simulated synthetic organic fraction of municipal solid waste and reported that $21-23 \%$ of total prokaryotes were Archaea. Wang et al. [24] observed that in a digester fed with pre-treated food waste the proportion of Archaea contributed $12-18 \%$ to the total number of prokaryotes. Angenent et al. [25] digested swine manure and calculated a proportion of $15 \%$ Archaea within the total prokaryotes. A very high proportion of $64 \%$ Archaea within the total prokaryotes in a continuously operated, solely propionate fed chemostat can be calculated from the report of Shigematsu et al. [12] for a dilution rate of $0.3 \mathrm{~h}^{-1}$, indicating the selective enrichment of methanogens and presumably POB. As biowaste is a complex substrate there is a need of a larger spectrum of fermenting Bacteria than in digesters with propionate feeding, where only POB and eventually acetate-oxidizing bacteria (AOB) and $\mathrm{H}_{2} / \mathrm{CO}_{2}$, as well as acetate-utilizing methanogens, are required. Therefore, it seems plausible that the proportion of Archaea increased with an increasing OLR by propionic acid addition into the reactor.

A strong positive correlation (Pearson correlation 0.86) was found between numbers of Methanomicrobiales and biogas production. A supply of more propionate resulted in more biogas and in higher numbers of Methanomicrobiales, whereas the numbers of Methanosarcinales did not correlate well with biogas production or the higher concentration of propionate. This could mean that most of the methane derived from propionate degradation was generated by the hydrogenotrophic Methanomicrobiales community in conjunction with acetate-oxidizing bacteria (AOB) instead of Methanosarcinales. Since no acetate was accumulating in the reactor effluent and numbers of acetate-fermenting Methanosarcinales remained almost constant at increasing propionate OLRs, AOB may have been active, delivering $\mathrm{CO}_{2}$ and $\mathrm{H}_{2}$ for the Methanomicrobiales community. Methanosarcinales in the biowaste/propionate fed reactor stagnated for about 70 days (Figure 6d) and most of the acetate from propionate oxidation presumably was oxidized by AOB. An interaction of AOB and hydrogenotrophic methanogens for acetate cleavage to $\mathrm{CO}_{2}$ and hydrogen was already documented by Hori et al. [16]. It was reported that e.g., the number of Methanoculleus, a genus of Methanomicrobiales, correlated positively with the number of Pelotomaculum sp. (Pearson correlation 0.98) [14]. In the present study Methanoculleus sp. were not specially enumerated, but a positive correlation between Pelotomaculum and the number of Methanomicrobiales (Pearson correlation 0.79, [6]) was seen, which was in accordance with data from earlier work with the same source of biowaste [7,26]. There are, however, also examples of both high numbers of Pelotomaculum sp. and low numbers of Methanomicrobiales, which might indicate a dominance of aceticlastic methanogens [6]. A syntrophic association of Pelotomaculum sp., AOB, and members of Methanomicrobiales is another possibility but not a "conditio sine qua non" for growth on propionate, as reported by Moertelmaier et al. [7].

At relatively stable methane production (Figure 2b, days 85-90, after maintenance), cell numbers of Bacteria and of POB recovered, although propionate accumulated (formation $>$ degradation). Cell numbers of the three genera of POB increased at an OLR of $17-18 \mathrm{~kg} \mathrm{COD} \cdot \mathrm{m}^{-3} \cdot \mathrm{d}^{-1}$ (Figure $6 \mathrm{c}$ ). The maximum propionate degradation rate was around $2.6 \mathrm{~g} \cdot \mathrm{L}^{-1} \cdot \mathrm{d}^{-1}$ (calculated from data of Table 2 ) at a 
daily addition of $2.5 \mathrm{~g} \cdot \mathrm{L}^{-1}$ propionic acid into the reactor (contributing $4 \mathrm{~kg} \mathrm{CSB} \cdot \mathrm{m}^{-3} \cdot \mathrm{d}^{-1}$ to the OLR). Thus, only little propionate could have been generated from biowaste. When the reactor was fed with biowaste alone, up to $1.7 \mathrm{~g} \cdot \mathrm{L}^{-1}$ propionate was excreted. Propionate production was apparently suppressed during biowaste plus propionate feeding. Co-digestion of propionate seems to be a way to stabilize and increase the number of POB. Compared with the POB numbers in investigations with biowaste alone, the numbers of $\mathrm{POB}$ in digesters that were fed with biowaste + propionate were slightly higher: After the start of the full-scale biowaste digester of Karlsruhe $2-3 \times 10^{8}$ POB per mL were found in reactor effluent [6] and during co-digestion of biowaste with wheat and rye bread at high concentrations of propionate $2-5 \times 10^{8} \mathrm{POB}$ per $\mathrm{mL}$ were detected [26], whereas $5-6 \times 10^{8} \mathrm{POB}$ per $\mathrm{mL}$ were found after biowaste/propionate co-digestion (Figure $6 \mathrm{c}$ ).

When propionate was fed the most numerous POB were Pelotomaculum sp. $\left((5.1 \pm 1.6) \times 10^{8} \mathrm{~mL}^{-1}\right)$, followed by significantly less Syntrophobacter sp. $\left((8.4 \pm 0.3) \times 10^{7} \mathrm{~mL}^{-1}\right)$ and Smithella sp. $\left((1.1 \pm 0.9) \times 10^{7} \mathrm{~mL}^{-1}\right.$, Figure 6c). Pelotomaculum sp. and Syntrophobacter sp. began to grow when co-fermentation of $1 \mathrm{~kg} \mathrm{CSB} \cdot \mathrm{m}^{-3} \cdot \mathrm{d}^{-1}$ of propionate in the presence of $12 \mathrm{~kg} \cdot \mathrm{m}^{-3} \cdot \mathrm{d}^{-1}$ biowaste was started, whereas Smithella sp. began to grow only when $1.5 \mathrm{~kg}$ propionate $\cdot \mathrm{m}^{-3} \cdot \mathrm{d}^{-1}$ were present and then approached numbers of Syntrophobacter sp. However, at higher OLR Smithella sp. decreased again to much lower final cell numbers $\left(<10^{7} \mathrm{~mL}^{-1}\right)$ than Pelotomaculum sp. or Syntrophobacter sp. (>10 $\mathrm{mL}^{-1}$; Figure 6c, days 90-120). These results indicate that Smithella sp. are not able to compete with the dominant Pelotomaculum sp. and with Syntrophobacter sp. at very low or very high propionate levels.

\section{Conclusions}

Propionic acid as a model substrate for highly acidified organic liquids could immediately substitute for biowaste suspensions in a biowaste reactor. Addition of little propionate to biowaste suspensions improved the propionate oxidation activity in a biowaste reactor at increasing OLR. An almost constant daily biogas production could be maintained during manual feeding of a biowaste suspension twice a day from Monday to Friday (regular biowaste collection period) and continuous pump feeding of propionic acid as a concentrated model substrate for acidified liquid wastes on Saturday and Sunday, when no biowaste is collected. Propionate degradation rates (PDRs) were much higher after propionate feeding than after biowaste feeding. During 5 days' starvation the PDR decreased by 50\%, but remained higher in biowaste suspensions after propionate feeding than after biowaste feeding.

The total number of bacteria including POB increased with little propionate feeding to its maximum within a few days, while the archaeal community increased slowly for about 60 days. In the biowaste-fed reactors, members of the genus Pelotomaculum were the abundant POB. Members of the genera Syntrophobacter and Smithella were also present, but at much lower numbers. POB reach their maximum cell numbers 20-40 days after the start. Very low numbers of Smithella sp. were detected under starvation conditions or at high concentrations of propionate. Numbers of acetate-utilizing methanogens increased only slowly but not proportionally to maximal cell numbers of Bacteria, whereas cell numbers of Methanomicrobiales increased faster and proportionally to numbers of Bacteria with increasing propionate load and reached a much higher cell density after about 70 days. 


\section{Acknowledgments}

We thank Amt für Abfallwirtschaft Karlsruhe for providing biowaste suspension from separately collected biowaste and for inocula from the full-scale digester, and Deutsche Forschungsgemeinschaft (DFG) for financial support (Grant Ga 546/4-2).

\section{Author Contributions}

All authors participated in conceiving and designing the experiments, Chaoran Li and Christoph Moertelmaier performed the experiments and analyses. Data evaluation was done by all authors, who also contributed to writing the paper.

\section{Conflicts of Interest}

The authors declare no conflict of interest.

\section{References}

1. McMahon, K.; Theng, D.; Stams, A.; Mackie, R.; Raskin, L. Microbial population dynamics during start up and overload conditions of anaerobic digesters treating municipal solid waste and sewage sludge. Biotechnol. Bioeng. 2004, 87, 823-834.

2. Gallert, C.; Henning, A.; Winter, J. Scale-up of anaerobic digestion of the organic fraction from domestic wastes. Water Res. 2003, 37, 1433-1441.

3. Gallert, C.; Winter, J. Bacterial metabolism in wastewater treatment systems. In Environmental Biotechnology —Concepts and Applications; Jördening, H.J., Winter, J., Eds.; Wiley-VCH: Weinheim, Germany, 2005; pp. 1-48.

4. Gallert, C.; Winter, J. Propionic acid accumulation and degradation during start-up of anaerobic biowaste digestion. Bioresour. Technol. 2008, 99, 170-178.

5. Li, J.; Ban, Q.; Zhang, L.; Jha, A.K. Syntrophic propionate degradation in anaerobic digestion: A review. Int. J. Agric. Biol. 2012, 14, 843-850.

6. Moertelmaier, C. KIT, Karlsruhe Institute of Technology, Karlsruhe, Germany. Propionate-Oxidizing Bacteria in Anaerobic Biowaste Digesters. Unpublished Data, 2015.

7. Moertelmaier, C.; Li, C.; Winter, J.; Gallert, C. Fatty acid metabolism and population dynamics in a wet biowaste digester during re-start after revision. Bioresour. Technol. 2014, 166, 479-484.

8. Li, C.; Mörtelmaier, C.; Winter, J.; Gallert, C. Effect of moisture of municipal biowaste on start-up and efficiency of mesophilic and thermophilic dry anaerobic digestion. Bioresour. Technol. 2014, 168, 23-32.

9. Gallert, C.; Winter, J. Verfahren der Abwasserreinigung. In Industrielle Mikrobiologie; Sahm, H., Antranikian, G., Stahmann, K.P., Takors, R., Eds.; Springer-Verlag: Berlin/Heidelberg, Germany, 2013; pp. 271-295.

10. De Bok, F.; Harmsen, H.; Plugge, C.; de Vries, M.; Akkermans, A.; de Vos, W.; Stams, A. The first true obligately syntrophic propionate-oxidizing bacterium, Pelotomaculum schinkii sp. nov., co-cultured with Methanospirillum hungatei, and emended description of the genus Pelotomaculum. Int. J. Syst. Evolut. Microbiol. 2005, 55, 1697-1703. 
11. Felchner-Zwirello, M.; Winter, J.; Gallert, C. Interspecies distances between propionic acid degraders and methanogens in syntrophic consortia for optimal hydrogen transfer. Appl. Microbiol. Biotechnol. 2013, 97, 9193-9205.

12. Shigematsu, T.; Era, S.; Mizuno, Y.; Ninomiya, K.; Kamegawa, K.; Morimura, S.; Kima, K. Microbial community of a mesophilic propionate-degrading methanogenic consortium in chemostat cultivation analyzed based on $16 \mathrm{~S}$ rRNA and acetate kinase genes. Appl. Microbiol. Biotechnol. 2006, 72, 401-415.

13. Ban, Q.; Li, J.; Zhang, L.; Jha, A.K.; Zhang, Y. Quantitative analysis of previously identified propionate-oxidizing bacteria and methanogens at different temperatures in an UASB reactor containing propionate as a sole carbon source. Appl. Biochem. Biotechnol. 2013, 171, 2129-2141.

14. Ariesyady, H.; Ito, T.; Yoshiguchi, K.; Okabe, S. Phylogenetic and functional diversity of propionate-oxidizing bacteria in an anaerobic digester sludge. Appl. Microbiol. Biotechnol. 2007, 75, 673-683.

15. Li, J.; Rui, J.; Pei, Z.; Sun, X.; Zhang, S.; Yan, Z.; Wang, Y.; Liu, X.; Zheng, T.; Li, X. Strawand slurry-associated prokaryotic communities differ during co-fermentation of straw and swine manure. Appl. Microbiol. Biotechnol. 2014, 98, 4771-4780.

16. Hori, T.; Haruta, S.; Ueno, Y.; Ishii, M.; Igarashi, Y. Dynamic transition of a methanogenic population in response to the concentration of volatile fatty acids in a thermophilic anaerobic digester. Appl. Environ. Microbiol. 2006, 72, 1623-1630.

17. Nayono, S.E.; Gallert, C.; Winter, J. Foodwaste as a co-substrate in a fed-batch anaerobic biowaste digester for constant biogas supply. Water Sci. Technol. 2009, 59, 1169-1178.

18. APHA. AWWA; WEF. In Standard Methods for the Examination of Water and Wastewater, 21st ed; American Public Health Association: Washington, DC; New York, NY, USA, 2005.

19. Amann, R.I.; Binder, B.J.; Olson, R.J.; Chisholm, S.W.; Devereux, R.; Stahl, D.A. Combination of 16S rRNA-targeted oligonucloetide probes with flow cytometry for analyzing mixed microbial populations. Appl. Environ. Microbiol. 1990, 56, 1919-1925.

20. Daims, H.; Lücker, S.; Wagner, M. Daime, a novel image analysis programe for microbial ecology and biofilm research. Environ. Microbiol. 2006, 8, 200-213.

21. Pullammanppallil, P.C.; Chynoweth, D.P.; Lyberatos, G.; Svoronos, S.A. Stable performance of anaerobic digestion in the presence of a high concentration propionic acid. Bioresour. Technol. 2001, 78, 165-169.

22. Amani, T.; Nosrati, M.; Mousavi, S.M.; Kermanshahi, R.K. Study of syntrophic anaerobic digestion of volatile fatty acids using enriched cultures at mesophilic conditions. Int. J. Environ. Res. 2011, 5, 333-342.

23. Nayono, S.E.; Gallert, C.; Winter, J. Co-digestion of press water and food waste in a biowaste digester for improvement of biogas production. Bioresour. Technol. 2010, 101, 6998-7004.

24. Wang, J.; Liu, X.; Kao, J.; Stabnikova, O. Digestion of pre-treated food waste in a hybrid anaerobic solid-liquid (HASL) system. J. Chem. Technol. Biotechnol. 2006, 81, 345-351.

25. Angenent, L.; Shihwu, S.; Raskin, L. Methanogenic population dynamics during startup of a full-scale anaerobic sequencing batch reactor treating swine waste. Water Res. 2002, 36, 4648-4654. 
26. Li, C.; Moertelmaier, C.; Winter, J.; Gallert, C. Co-digestion of wheat and rye bread suspensions with the source-sorted municipal biowaste fraction. Waste Manag. 2015, revised.

(C) 2015 by the authors; licensee MDPI, Basel, Switzerland. This article is an open access article distributed under the terms and conditions of the Creative Commons Attribution license (http://creativecommons.org/licenses/by/4.0/). 